\title{
PEMBINAAN INDUSTRI KREATIF PADA JIWA KEWIRAUSAHAAN MASYARAKAT
}

\author{
Zefri Azharman \\ Universitas Putera Batam (UPB), Batam, Indonesia \\ e-mail: zefriazharman91@gmail.com \\ Elva Susanti \\ Universitas Putera Batam (UPB), Batam, Indonesia \\ e-mail: elvasusanti89@gmail.com
}

\begin{abstract}
Human resources $(H R)$ are important in the industrial world, without human resources, natural resources will not develop into high-value finished materials. Knowledge towards the creative industry is not yet available if it has not been given to the community, therefore the community needs to be fostered in the field of creative industries in terms of changing raw materials into finished materials, in terms of changing unused materials into finished goods, in terms of how to find the right opportunities in the field small industries and so on. With the guidance of the community, it is expected that the community will be able to be creative and understand the importance of the creative industry in the field of entrepreneurship. The creative industry implemented is the manufacture of healthy salted eggs without harmful chemical preservatives. Utilizing rubbing ash and salt can increase the resistance of duck / duck eggs and provide a high selling price. The activities carried out are needed by the PKK community who routinely carry out creative activities including the creative industries to increase entrepreneurship.
\end{abstract}

Keywords - The creative industry, salted eggs, entrepreneurship,

\section{PENDAHULUAN}

Pe erkembangan zaman dan teknologi yang semakin canggih, merambat kepada setiap aspek kehidupan, tingkat persaingan yang semakin tinggi memaksa setiap orang lebih jeli dalam membaca setiap peluang dalam usaha mengembangkan keterampilan dan keahliannya untuk menjawab tantangan zaman. Rendahnya tingkat keterampilan dan keahlian yang dimiliki oleh sebagian besar penduduk Indonesia merupakan salah satu alasan kenapa angka pengangguran di Indonesia semakin meningkat. Padahal usaha yang dilakukan pemerintah dalam memberantas kemiskinan dan kebodohan sudah menjadi agenda utama dari pemerintah. Salah satu contoh yaitu dengan mencetuskan wajib belajar 9 Tahun dan memberikan pinjaman dengan suku bunga ringan untuk meningkatkan taraf hidup bangsa Indonesia tersebut. Namun semua itu ternyata tidaklah cukup, karena belum didukung oleh sumber daya manusia yang terampil dan berkeahlian yang dapat dimanfaatkan untuk membuka peluang usaha, menciptakan lapangan kerja sendiri, atau berkreasi yang menghasilkan tentunya yang dapat berdampak pada penekanan terhadap tingginya angka pengangguran, tingginya angka kemiskinan yang ada di Indonesia tersebut. Dilingkungan sekolah pun jarang sekali memperkenalkan ilmu industri kreatif dibidang kewirausahaan, salah satunya adalah pembinaan pembuatan telur asin. 
Telur asin terbuat dari pengawetan telur bebek. Telur bebek sebagai bahan pangan yang cukup sempurna mengandung zat gizi tinggi yang mudah dicerna, kaya protein, lemak dan zat-zat lain yang dibutuhkan tubuh. Kandungan protein dalam telur bebek cukup tinggi, yakni 13,1 gram per 100 gram dibandingkan dengan telur ayam 12,8 gram (Nuruzzakiah, Rahmatan, \& Syafrianti, 2016). Dalam pembuatan telur asin dengan konsentrasi larutan garam sebesar $20 \%$ dan $25 \%$ dengan tanpa adanya pemberian tekanan, dan konsentrasi larutan garam $20 \%$ dengan tekanan 1.5 bar menghasilkan telur asin yang lebih disukai. Pada kombinasi perlakuan tersebut menghasilkan telur asin yang bertekstur masir pada kuning telur dan tidak terlalu asin pada bagian putih telurnya (Rukmiasih, Ulupi, \& Indriani, 2015). Telur asin memiliki langkah pembuatan yang tidak rumit dan dapat dilakukan oleh siapa saja dengan alat yang mudah didapatkan dan memiliki kandungan yang bermanfaat. Oleh karena itu, kami tim dosen akan melakukan pembinaan industri kreatif dengan pemanfaatan bahan alami sebagai pengawetan telur sebagai pembinaan Ibu PKK. Sasaran yang diharapkan dari kegiatan ini adalah untuk memberi pemahaman serta pembinaan pentingnya industri kreatif kepada masyarakat. Salah satunya adalah pengawetan telur bebek dengan bahan alami $\mathrm{NaCl}$ yang dibutuhkan oleh Ibu PKK.

\section{METODE}

Untuk menunjang pembinaan yang dilakukan tersebut supaya berjalan sukses dan lancar maka dapat disebutkan beberapa peralatan yang yang antara lain adalah sebagaia berikut:

1. Laptop,

2. Kertas, pena, gunting, dan lain-lain,

3. Telur bebek, abu gosok, garam, wadah, sabut kelapa atau amplas, dan air.

\subsection{Tahapan Pelaksanaan}

Untuk metode pelaksanaan kegiatan pembinaan sendiri ada beberapa hal yang perlu dilakukan diantaranya adalah sebagai berikut:

1. Memberikan pengarahan tentang industri kreatif,

2. Memberikan pengarahan bagaimana mengelola telur asin,

3. Memberikan pengarahan bagaimana memproduksi telur asin.

Untuk melihat apakah hasil pembinaan kepada masyarakat ini berjalan dengan lancar dan sukses maka perlu dilakukan evaluasi untuk mengukur keberhasilan dalam pembinaan di perumahan Maitri Indah perlu dilakukan evaluasi yaitu dengan melakukan uji coba hasil dari pengasinan telur dengan cara merebus telur asin pada sesi pembinaan sesuai dengan jadwal yang telah di susun.

Sehingga nantinya hasil kegiatan dari pembinaan ini adalah masyarakat pada perumahan Maitri Indah dapat mengetahui cara pembuatan telur asin dan melakukan kegiatan wirausahaan sampingan sehingga dapat meningkatkan perekonomian keluarga atau membuka lapangan pekerjaan.

\section{HASIL DAN PEMBAHASAN}

\subsection{Hasil Pengabdian}

Dengan adanya program kegiatan pengabdian yang diselenggarakan oleh pihak kampus Universitas Putera Batam, dengan lokasi pengabdian di Perumahan Maitri Indah, ada beberapa hal yang diperoleh adalah: 
1. Dapat membangun hubungan dan kerjasama yang baik antara pihak Universistas Putera Batam dengan masyarakat umum khususnya di Perumahan Maitri Indah.

2. Dapat menambah pengalaman untuk tim pengabdi terkhususnya untuk saya sendiri dalam berkomunikasi dengan baik antara masyarakat yang berada di wilayah perumahan Maitri Indah tersebut.

3. Dapat menambah ilmu, pengalaman dan pelajaran bagi peserta binaan, dari yang tidak tahu menjadi tahu dan dari yang kurang memahami Pengawetan/Pengasinan telur bisa menjadi lebih paham dan mengaplikasikannya.

4. Dapat mengembangkan dan berbagi pengalaman tentang pentingnya pengawetan dengan garam $(\mathrm{NaCL})$ sebagai pengawetan/pengasinan untuk pengolahan telur.

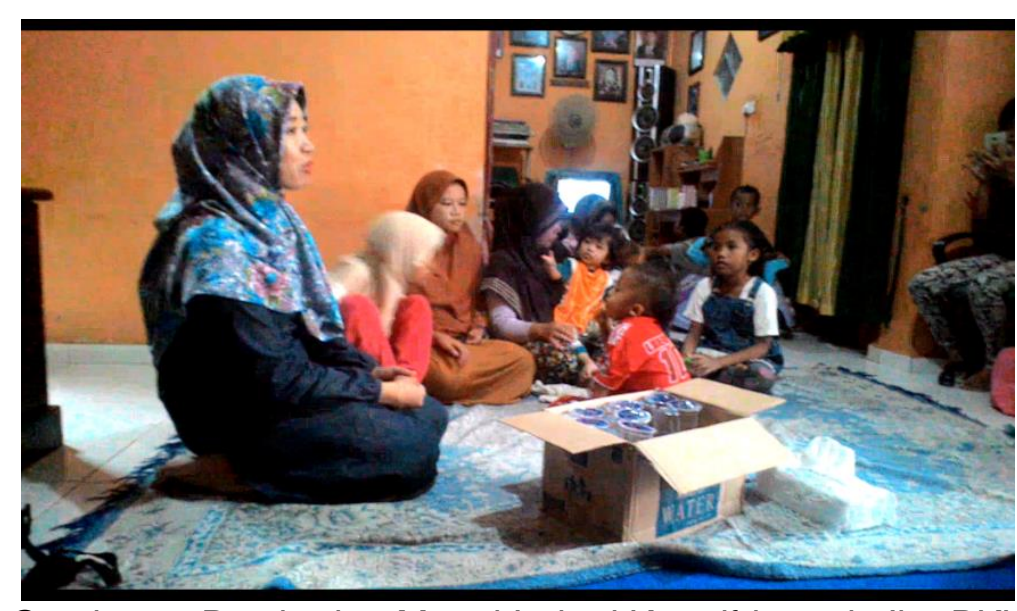

Gambar 1. Pemberian Materi Indutri Kreatif kepada Ibu PKK

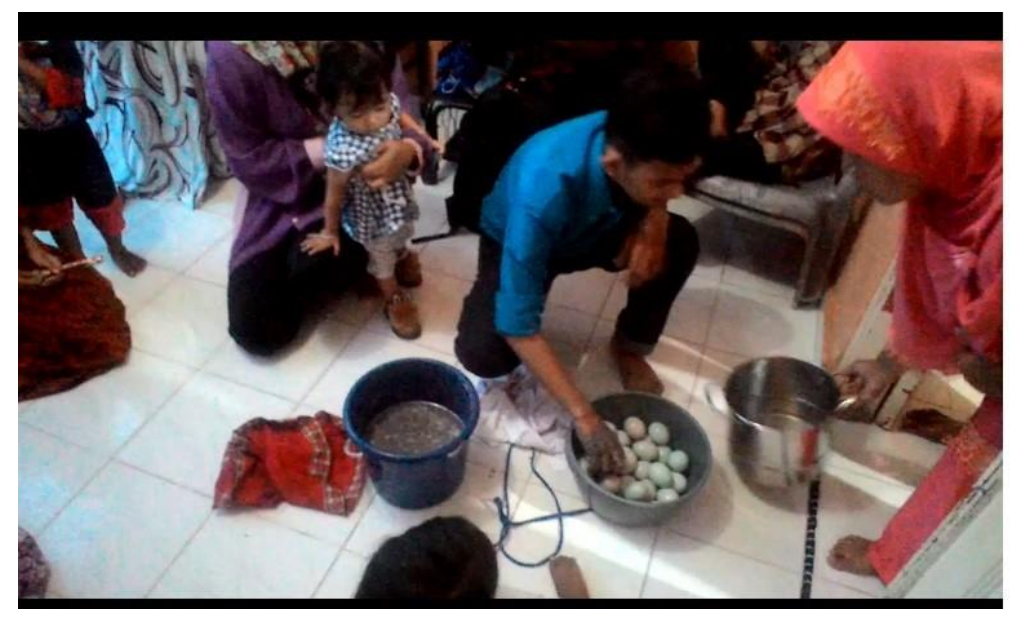

Gambar 2. Hasil Pembuatan Telur Asin

\subsection{Pembahasan}

Untuk menunjang suksesnya acara pembinaan kepada masyarakat atau Ibu PKK yang bertempat di Perumahan Maitri Indah, saya bersama rekan dosen lain telah melakukan beberapa hal, secara garis besar dapat dijelaskan antara lain adalah sebagai berikut:

\subsubsection{Pelaksanaan Kegiatan}


Berdasarkan dari table 3.1 untuk pelaksanaan kegiatan pembinaan tidak jauh berdasarkan dari susunan acara. Setiap tim pengabdi diberikan waktu dan kesempatan untuk menyampaikan materi yang sesuai dirancang bersama oleh tim pelaksana pengabdi di Maitri Indah.

\subsubsection{Faktor Pendukung dan Penghambat}

Selama melaksanakan sebuah kegiatan pengabdian masyarakat berupa pembinaan tidak terlepas dari faktor-faktor yang akan mendukung dan menghambat terlaksananya kegiatan tersebut. Hal ini tentunya bukan menjadi penghalang utama, karena sebagai pengabdi hal-hal tersebut harus bisa diatasi secara baik, hal ini dapat dibuktikan dengan terlaksananya proses pengabdian dari awal sampai dengan akhir dengan baik dan lancar. Berikut adalah beberapa faktor penghambat serta pendukung selama proses pengabdian berlangsung.

1. Faktor Pendukung.

Faktor yang mendukung terlaksananya pengabdian masyarakat berupa pembinaan di Perumahan Cipta Asri ini adalah:

1. Hangatnya tanggapan dari Ketua RT (Rukun Tetangga) di Perumahan Maitri Indah dalam melaksanakan kegiatan Pembinaan untuk Masyarakat atau Ibu PKK di lingkungan tersebut.

2. Ruangan pembinaan diberikan khusus dirumah salah satu warga di Perumahan Maitri Indah.

3. Para peserta pembinaan sudah siap dengan diadakannya pembinaan ini, dengan cara memberikan dan meluangkan waktu mereka untuk kegiatan pembinaan.

2. Faktor Penghambat.

Sedangkan faktor yang menghambat terlaksananya pengabdian masyarakat pada Perumahan Maitri Indah adalah susahnya mencari jadwal yang tepat untuk melaksanakan kegiatan karena peserta ada yang bekerja dan adanya kegiatan masyarakat pada pertemuan kedua.

\section{KESIMPULAN}

Dari pelaksanaan pembinaan industri kreatif dalam pengawetan/ pengasinan telur bebek kepada masyarakat atau Ibu PKK di Perumahan Maitri Indah, maka dapat di tarik kesimpulan antara lain sebagai berikut:

1. Pengabdian pembinaan yang telah dilakukan memberikan pemahaman kepada masyrakat bahwa pngasinan telur bebek mudah untuk dilakukan.

2. Pengawetan/pengasinan telur dengan bahan alami yaitu garam sangat potensial dalam mempertahankan telur dari cepat busuk dan meningkatkan nilai jualnya.

\section{SARAN}

Saran yang dapat diberikan kepada para peserta pembinaan di Perumahan Maitri Indah adalah sebaiknya peserta pembinaan juga mengaplikasikan kembali cara pengasinan di rumah atau dalam sekala kecil. 


\section{UCAPAN TERIMA KASIH}

Penulis mengucapkan terima kasih kepada Lembaga Penelitian dan Pengabdian Masyarakat Universitas Putera Batam yang telah memberi dukungan terhadap pengabdian ini.

\section{DAFTAR PUSTAKA}

Nuruzzakiah, Rahmatan, H., \& Syafrianti, D. (2016). Pengaruh Konsentrasi Garam Terhadap Kadar Protein dan Kualitas Organoleptik Telur Bebek. Jurnal Ilmiah Mahasiswa Pendidikan Biologi, 2002(1), 35-40. https://doi.org/10.1109/ciced.2018.8592188

Rukmiasih, Ulupi, N., \& Indriani, W. (2015). Sifat Fisik, Kimia Dan Organoleptik Telur Asin Melalui Penggaraman Dengan Tekanan Dan Konsentrasi Garam Yang Berbeda. Jurnal Ilmu Produksi Dan Teknologi Hasil Peternakan, 3(3), 142-145. https://doi.org/10.29244/jipthp.3.3.142-145 
